\title{
Prospective mathematics teachers' critical thinking processes about scientific research: Newspaper article example
}

\author{
Mehtap Kuş \\ Aksaray University, Faculty of Education, Aksaray, Turkey, ozenmehtap@gmail.com \\ Erdinç Çakıroğlu (D) \\ Middle East Technical University, Faculty of Education, Ankara, Turkey, erdinc@ metu.edu.tr
}

Check for updates

\begin{abstract}
This study aimed to explore how prospective middle school mathematics teachers think critically about a newspaper article that reported the findings of a statistical research. Participants of the study were four fourth-year students enrolled at the mathematics teacher education program of a public university. To investigate the research question of the study, case study method was employed. Indepth semi-structured interviews were done to examine participants' critical thinking processes. The findings of the study indicated that prospective mathematics teachers made use of a variety of critical thinking processes (comprehending, making connections, inferring ideas, critiquing, and selfreflecting) and provided clues about the interrelated nature of these processes. This study would shed light on the characterization of critical thinking in the context of statistical literacy by suggesting a blended framework. It also suggests the design of the tasks including media articles to promote both statistical literacy and critical thinking in statistics education courses for prospective mathematics teachers.
\end{abstract}

Keywords: Critical thinking, Mathematics education, Media texts, Statistical literacy, Teacher training

\section{Matematik öğretmeni adaylarının bilimsel araştırma hakkındaki eleştirel düşünme süreçleri: Gazete haberi örneği}

ÖZ Bu çalışmanın amacı, ortaokul matematik öğretmeni adaylarından istatistiksel bir araştırmanın bulgularını sunan bir gazete haberini okumaları istendiğinde öğretmen adaylarının nasıl eleştirel düşündüklerini incelemektir. Çalışmanın katılımcıları bir devlet üniversitesinde öğrenim gören dört son sınıf ortaokul matematik öğretmeni adayıdır. Araştırmanın amacına uygun olarak, durum çalışması yönteminden yararlanılmıştır. Çalışmanın ana veri toplama kaynağını, öğretmen adaylarıyla yapılan görüşmeler oluşturmaktadır. Yarı yapılandırılmış görüşmeler aracılığıyla katılımcıların eleştirel düşünme süreçleri derinlemesine incelenmiştir. Bu çalışmanın bulguları, ortaokul matematik öğretmeni adaylarının bilimsel araştırma içeren bir gazete haberini okurken çeşitli eleştirel düşünme süreçlerinden (anlama, bağlantı kurma, çıkarım yapma, eleştirme ve yansıtıcı düşünme) yararlandıklarını ortaya koymaktadır. Aynı zamanda bu eleştirel düşünme süreçlerinin birbirleriyle ilişki olduğuna dair ipuçları sunmaktadır. Bu çalışmanın, istatistiksel okuryazarlık bağlamında eleştirel düşünmenin tanımlanmasına ilişkin harmanlanmış bir teorik çerçeve sunarak, istatistik eğitimi ve eleştirel düşünme çalışmalarına 1şık tutacağı öngörülmektedir. Ayrıca bu çalışma, matematik öğretmeni adayları için istatistik eğitimi derslerinde hem eleştirel düşünme hem de istatistiksel okuryazarlığın geliştirilmesi için medya metinleri içeren ders içeriklerinin geliştirilmesini önermektedir.

Anahtar Sözcükler: $\quad$ Eleştirel düşünme, Istatistiksel okuryazarlı, Matematik eğitimi, Medya metinleri, Öğretmen yetiştirme

Citation: Kuş, M. \& Çakıroğlu, E., (2020). Prospective mathematics teachers' critical thinking processes about scientific research: Newspaper article example. Turkish Journal of Education, 9(1), 22-45. DOI: $10.19128 /$ turje. 605456 


\section{INTRODUCTION}

Parallel to the rapid progress in science and technology, new skills and literacies relevant to the challenges of 21 st-century have been emphasized by many educators. School systems around the world are being encouraged to consider the development of such literacies and skills in their curricula (e.g., Jacobs, 2010; Wagner, 2014). One of the important skills for individuals in an information society is statistical literacy (Gal, 2002; Gould, 2017), which has a significant role in being individuals who evaluate claims and arguments and make effective decisions in their life (Moore, 1998). Today, individuals are surrounded by an enormous amount of information from diverse sources. Many of the information individuals reach involve statistical aspects in them (Schield, 2004), which often include conclusions from statistical evidence. However, information released by these sources might be misleading and conflicting, and involve one-sided claims or arguments (Gal, 2002). To cope with such information, individuals need to critically review the information in the media texts before they develop ideas based on them. Otherwise, it would be difficult for individuals to develop sound ideas about the phenomena around them without having statistical literacy. Thus, statistical literacy is needed to make efficient decisions about social, political, economic and health issues in personal life and in workplaces, rather than blindly adopt misleading information released in the media texts $(\mathrm{Gal}, 2002)$.

Studies on statistics education put emphasis on the use of real-life contexts in teaching and learning of statistics (Ben-Zvi \& Garfield, 2008; Gal, 2002; Utts, 2003; Watson, 1997). In this sense, media texts such as newspaper articles can be considered as a tool for supporting students' statistical literacies in context, since they often involve statistical information regarding daily life issues (Watson, 1997). In order to help students to develop a critical perspective about statistical information around them, instead of merely dealing with computations, students can be asked to interpret and critically question the information presented in the media (Watson, 1997). In addition, Jarman and McClune (2007) suggested that teachers can use the media texts to alert students to be aware of the strengths and limitations of such reports in the context of scientific literacy, which focuses more on critical reading of scientific issues (e.g., genetics, astronomy, energy) and scientific research process. In this sense, the construct of critical thinking can be considered as a valuable phenomenon to consider in studying statistical education.

Critical thinking has been emphasized as an educational goal by various researchers (e.g., Ennis, 1985; Facione, 1990; Halpern, 1998; Kennedy, Fisher, \& Ennis, 1991; Kuhn, 1999; Paul, 1984; Siegel, 1988). Critical thinking has been considered as one of the primary goals of education since people need to be active critical citizens in the society (Kennedy et al., 1991) and to cope with misleading or fallacious information in the social and scientific texts (Lin, 2014; Norris \& Phillips, 2012; Vieira \& Tenreiro-Vieira, 2016). In spite of such an emphasis, several studies on statistical thinking pointed out that students mostly have lack of statistical and mathematical knowledge to comprehend scientific research in the media articles and tend to receive information conveyed in the articles without any criticism (Watson, 2006). In the future, to nurture students as critical thinkers in schools, an important first step is to train prospective teachers as individuals who can think critically. If teachers have lack of statistical knowledge and critical sense while reading real-life contexts, it would hinder students' development of statistical literacy (Watson, Callingham, \& Nathan, 2009). Various curriculum documents also put emphasis on the importance of thinking critically in the out-of-school contexts such as media texts (Australian Education Council [AEC], 1991; Ministry of National Education of Turkey [MoNE], 2018; National Council of Mathematics Teachers [NCTM], 2000). 
It should be noted that, in order to provide students with effective learning experiences that help them to think critically on statistical concepts, schools rely on mathematics teachers' knowledge and skills (Batanero \& Diaz, 2010; Burrill \& Biehler, 2011; Chesler, 2015). In Turkey and other countries (e.g., the US, New Zealand) the mathematics curriculum was revised by paying attention to statistics education (Cantürk-Günhan, Bukova-Güzel \& Özgür, 2012). Such attention on statistics, as a new learning domain of mathematics education, requires prospective teachers' training and revision of current statistics courses in teacher education programs. Even if the curriculum documents emphasize and gave attention to statistics education, learning of statistics depends on the teachers' capacity. However, most of the teachers do not have sufficient experiences in learning of statistics (Zhang \& Stephens, 2016), particularly, prospective mathematics teachers who are future teachers of statistics in the school mathematics (Gattuso \& Ottaviani, 2011). In teacher education programs prospective teachers were mostly taught statistics by mathematics educators who have not been particularly trained in statistics education (Batanero, Burrill, \& Reading, 2011). They were often taught about theoretical statistics in introductory statistics courses and there is need for professional training of mathematics teachers to teach statistics (Batanero \& Diaz, 2010). Prospective teachers should be prepared to teach statistics concepts and statistical literacy (Batanero, Burrill, \& Reading, 2011; Burrill \& Biehler, 2011). Teacher education programs should start to provide opportunities of instructional practices of statistics and development of thinking skills (statistical and critical thinking) (Aizikovitsh-Udi, Kuntze, Clarke, 2016). Teachers should be trained to be critical thinkers about the use of statistics in media contexts (Chesler, 2015) and have pedagogical content knowledge to promote students' critical thinking and use of statistics in real-life contexts (Watson \& Nathan, 2010). In spite of such an emphasis and concerns on mathematics teacher education programs, there has been very few studies on teacher education on this issue (Chesler, 2015). In-depth investigation of critical thinking processes of prospective mathematics teachers who are taught in the current teacher education programs would be a crucial initial step for training of prospective teachers in teaching statistics, particularly in the context of statistical literacy. It would, in turn, reflect deficiencies in teaching of statistics in teacher education programs and shed light into design of the statistics courses.

There have been scarce studies on investigation of prospective teachers' critical thinking in the media texts; but also, on interpretation of critical thinking in the context of statistical literacy even though they are related constructs (Budgett \& Pfannkuch, 2010; Gal, 2002; Watson \& Callingham, 2003). Critical thinking and its components have been often described from the philosophical, psychological, and cognitive perspectives in education by various researchers (e.g., Ennis, 1985; Facione, 1990). However, there is need for describing critical thinking in the context of statistics education (Kuntze, Aizikovitsh-Udi, \& Clarke, 2017), particularly statistical literacy, which is highly related construct with critical thinking (Gal, 2002). This study addresses this gap by investigating how prospective mathematics teachers think critically about a media text involving scientific research and by adapting theoretical framework of critical thinking to the statistical literacy context. To achieve this goal, we made use of critical thinking framework proposed by Facione (1990) as it provides comprehensive explanation of components of critical thinking, exemplify how strong critical thinkers think and it has potential to be transferable to the different domains. In-depth investigation of prospective mathematics teachers' critical thinking processes based on a theoretical framework would be a crucial step to address the problem discussed above, which would in turn enlighten the design of the statistics courses in teacher education programs. In this regard, we aim to investigate the following question:

How do prospective middle school mathematics teachers think critically when they are reading a scientific research published in a newspaper article?

\section{Conceptualization of Critical Thinking}

Critical thinking and its components were defined by several researchers (Ennis, 1985; Facione, 1990; McPeck, 1990; Paul, 1984). Ennis (1985) defined critical thinking as "reflective and reasonable thinking that is focused on deciding what to believe or do" (p. 45). He identified the characteristics of individuals who think critically through several cognitive skills (e.g., thinking about the quality and 
credibility of arguments, drawing conclusions with a carefulness, clarifying ideas appropriately) and dispositions (e.g., being open to alternatives, making an effort to be informed). Similarly, Paul (1984) defined critical thinking based on mastery of skills and dispositions such as being autonomous, persevering, and open minded to avoid egocentrism. Facione (1990), in a further study, proposed a comprehensive framework including cognitive skills and dispositions based on the consensus among forty-six experts. These cognitive skills include interpretation, analysis, evaluation, self-regulation, inference, and explanation and their subskills. He also reported a list of dispositions (e.g., being openminded, willing to search for truth, being alert to use critical thinking), supportively previous studies on critical thinking.

Studies on critical thinking highlighted a clear agreement among researchers on the components of critical thinking as a blend of skills and dispositions. However, there has been a disagreement on whether these skills are generalizable to other domains or they should be subject-specific skills and cannot be generalized (ten Dam \& Volman, 2004). This disagreement among researchers is not scope of this paper. This study holds a view compatible with the study of Facione (1990) in which he suggested critical thinking could be transferred to a wide range of subject matter domains. We made use of the critical thinking framework proposed by Facione (1990) as a guide to identify prospective mathematics teachers' critical thinking processes when they were reading a scientific research conveying statistical information in a newspaper article, which were represented through using mathematical ideas such as percents or probability. In other words, this study involves the blending cognitive processes of critical thinking with statistical literacy required for making sense of media texts.

\section{Critical Thinking and Statistical Literacy}

In the statistics education literature, statistical literacy was defined by several researchers (delMas, 2002; Gal, 2002; Rumsey, 2002; Schield, 1999; Wallman, 1993; Watson, 1997). In this study, we focus on statistical literacy and look through the lenses of statistical literacy, particularly defined by Gal (2002). He defined statistical literacy as interpreting and critically evaluating claims or arguments in social and scientific texts and communicating about them. Several researchers proposed models to assess statistical literacy. They included critical thinking in their models of statistical literacy as a list of worry questions (Gal, 2002), as a last tier (questioning claims) (Watson, 1997), as the last stage (critical and critical-mathematical) in the hierarchical level of statistical literacy (Watson \& Callingham, 2003), and as trigger elements (heuristics and fallacies and worry questions) (Budgett \& Pfannkuch, 2010). The authors did not use the term of critical thinking explicitly in their conceptualization of statistical literacy. They included some components of critical thinking such as questioning claims and using mathematical and statistical knowledge to interpret the claims. Even though they included some points on critical thinking, they did not discuss what critical thinking refers to and how it could be defined in a comprehensive way in the context of statistical literacy.

In the critical thinking literature, several research reports emphasized the role of statistical knowledge in critical reading of the texts (Ennis \& Weir, 1985; Facione, 2011; Halpern, 1998). For example, Ennis and Weir (1985) in their essay test on critical thinking included essays directly related with statistics to measure students' judgment level. These essays required students to recognize bias in the essays, sampling, and causality. Halpern (1998) also included two categories directly related to statistics in her taxonomy of critical thinking skills: (1) thinking as hypothesis testing (e.g., considering sample size, generalizability) and (2) understanding likelihood and uncertainty to make decisions (p. 452). Recently, Facione (2011) also pointed out that people should think about the extent to which inductive arguments could be generalizable with taking into account of some statistical concepts (e.g., sample representativeness and sampling), know the difference between correlation and causality, and recognize overgeneralizations and exaggerated numbers. Even though the focus of these studies is not on the statistics and probability, they provide some instances of the relationship between critical thinking and statistical literacy. The studies on statistical literacy and critical thinking provide clues about interrelated nature of critical thinking and statistical literacy. It provides motivation for 
conducting this study and investigating critical thinking in the context of statistics education. In the current study, in order to contribute to the conceptualization of critical thinking in statistics education, prospective teachers' analyses of a newspaper article that include statistical information were investigated through the lenses of critical thinking framework proposed by Facione (1990).

\section{METHODOLOGY}

The case study was employed to investigate prospective mathematics teachers' critical thinking processes when they were asked to read a scientific research published in a newspaper article. The reason of the case study was in-depth examination of fourth-year prospective mathematics teachers' critical thinking processes, who were on the brink of graduation from teacher education program and completed statistics and probability and research methods courses.

\section{Participants}

Participants of the study were four prospective middle school mathematics teachers. They were selected among 38 fourth-year students who were enrolled in an undergraduate teacher education program of a public university in Turkey. After graduation, they become candidates to work in middle schools as mathematics teachers for grade levels 5 to 8 . The teacher education program requires all students to take a course on Probability and Statistics as well as on Research Methods. In order to select the participants, researchers asked 38 fourth-year students, who were volunteered to participate to the study, to write down their reflections about statistical information in a newspaper article that is only used for participant selection. Four participants were chosen with respect to their potential to provide rich data by reflecting their thinking, tend to express their ideas with valid mathematical procedures, and detect critical points in the article in order to gain insight into their critical thinking processes. Four participants were willing to participate to the interviewing process. In the current study, they were given pseudonyms, namely Ali, Meltem, Melek, and İrem. All participants were majoring in mathematics education. In addition, Ali and Meltem had minor in statistics as a secondary domain and İrem had minor in mathematics department.

\section{Data Collection}

Semi-structured interviews were conducted to elicit prospective teachers' thinking processes in detail. Interviews were audio and video recorded, and lasted for forty-five minutes approximately. Participants were asked to read a newspaper article (Appendix 1) that Watson (2011) suggested to use it in classrooms. This article, reported in the Mercury newspaper of Tasmania, was about fidelity and infidelity of women and men ("Cheat radar better tuned in men, study finds", 2008). The language of original newspaper article was in English. It was translated into Turkish by the researchers and participants were asked to read this translated version.

The article involves probabilistic and statistical statements, especially related with conditional probability concept (Table 1). To make their thinking process visible, researchers asked some key questions about the article: "What is the main idea of the newspaper article? What conclusions did researchers reach according to newspaper article? What conclusions could you draw from the text? How could the researchers conduct the study reported in the newspaper article? (e. g. how to select sample, how to collect and analyze the data, how to reach reported findings) How would you evaluate reported findings? What do you think about generalizability of the reported statistics in the newspaper article?" In addition to these questions, researcher particularly asked participants what they understand from four statements (Table 1) in the newspaper article to gain insights into their thinking processes. 
The statements particularly involve conditional probability concept and they were expressed as percentages, which is one of the representations of probability (Gal, 2005) and requires proportional reasoning. Their thinking processes were elaborated through follow-up questions such as How can you express the statements mathematically? How could such a conclusion be reached? and How do you calculate it?"

Table 1.

Statements in the newspaper article

Statements

Statement 1 "The results, published in New Scientist, show 29 per cent of men admitted they had cheated compared with 18.5 per cent of women."

"Researcher Paul Andrews said men were better at judging fidelity than women. 'Eighty per cent

Statement 2 of women's inferences about fidelity or infidelity were correct, but men were even better, accurate 94 per cent of the time' Dr. Andrews said."

"Men were more likely to catch out a cheating partner, picking up on 75 per cent of the reported

Statement 3

infidelities compared with 41 per cent discovered by women."

"Men are better at detecting a cheating partner than females, and they are more likely to suspect

Statement 4 infidelities that do not exist."

\section{Data Analysis}

Data analysis was conducted to investigate the indicators of prospective middle school mathematics teachers' critical thinking processes about statistical information in the newspaper article. The framework proposed by Facione (1990) was used to identify critical thinking processes. In order to organize prospective teachers' thinking about statistical information, we made use of the statistical literacy frameworks of Gal (2002) and Watson (2006). In subsequent sections, we present briefly how we used existing frameworks on critical thinking and statistical literacy. These frameworks were used as a starting point to analyze the data. They were not entirely applicable to the context of our study. Thus, we made refinements to make them suitable with our data analysis, which resulted in a blended version of the frameworks of critical thinking and statistical literacy. We made some adaptations and refinements regarding some dimensions of the frameworks without making significant changes in the meanings of concepts.

\section{Adaptation of Critical Thinking Framework to the Context of Statistics and Probability}

In this study, we organized participants' responses about statistical information in the newspaper article at three broad dimensions: Base of reported findings, reported findings, generalizability of reported findings. In order to identify the participants' critical thinking instances, we adopted the framework developed by Facione (1990) using Delphi Method from the experts on critical thinking. They identified six cognitive skills of critical thinking and their sub-skills: Interpretation (categorization, decoding significance, clarifying meaning), analysis (examining ideas, detecting arguments, analyzing arguments), evaluation (assessing claims, assessing arguments), inference (querying evidence, conjecturing alternatives, drawing conclusions), explanation (stating results, justifying procedures, presenting arguments) and self-regulation (self-examination, self-correction) (p. 12). They highlighted that listing of the skills is not intended to indicate any order or hierarchical. Whereas some of them may overlap to each other, some skills may be prerequisite for the others in different contexts. We included all of the dimensions in the original framework, except the dimension of "explanation," since it was not observed in the data of our study. The reason why it was not observed in this study was due to the fact that "explanation" skill in the original framework was about presenting research results in a coherent way and justification of the claims or arguments concerning them. In this study participants read the statistical results already written by others and published in the newspaper article. Thus, they did not need to write or present statistical results and arguments about them. The other dimensions of the Facione's framework (1990) were included in the current 
study. We made revisions in the sub-dimensions to make them more suitable with the context of this study. They were restated respectively as the following: comprehending, making connections, inferring, critiquing, and self-reflecting. At the end of the data analysis process, we identified five interconnected critical thinking processes, which is resulted in a blended framework of critical thinking and statistics in the context of media texts. Each dimension with their brief explanations are presented in Table 2 .

Table 2.

Codes for analysis of critical thinking processes concerning statistics and probability

\begin{tabular}{|c|c|c|}
\hline $\begin{array}{l}\text { Critical thinking } \\
\text { skills }\end{array}$ & $\begin{array}{l}\text { Sub-skills of critical } \\
\text { thinking }\end{array}$ & Examples \\
\hline \multirow{3}{*}{ Comprehending } & $\begin{array}{l}\text { Identification of the } \\
\text { main idea of the text }\end{array}$ & $\begin{array}{l}\text { Determining the purpose of the reported study and distinguishing main idea or } \\
\text { purpose of the text from extraneous or irrelevant ideas in the newspaper article }\end{array}$ \\
\hline & $\begin{array}{l}\text { Organization of the } \\
\text { contextual information }\end{array}$ & $\begin{array}{l}\text { Constructing graph, table, diagram, or other visual displays that show } \\
\text { relationships between variables or findings of reported study in the newspaper } \\
\text { article, classifying information with the consideration of their attributes }\end{array}$ \\
\hline & $\begin{array}{l}\text { Clarification of the } \\
\text { information }\end{array}$ & $\begin{array}{l}\text { Restating or paraphrasing the words, phrases, and statements in the newspaper } \\
\text { article, recognizing ambiguous or vague terms of the research that are crucial } \\
\text { to understand the nature of reported study, making the meanings of the } \\
\text { statements explicit, particularly with the use of confusing language of } \\
\text { conditional probability }\end{array}$ \\
\hline $\begin{array}{l}\text { Making } \\
\text { Connections }\end{array}$ & $\begin{array}{l}\text { Examining links } \\
\text { between ideas }\end{array}$ & $\begin{array}{l}\text { Identifying the statements, ideas, concepts, expressions that are related to each } \\
\text { other, identifying similarities and differences between findings of the reported } \\
\text { study, searching for the prerequisite finding to understand another reported } \\
\text { finding and relating it with that finding, breaking up results or conclusions of } \\
\text { reported study into smaller parts or results }\end{array}$ \\
\hline \multirow{3}{*}{ Inferring } & Examining evidence & $\begin{array}{l}\text { Exploring the background information to make inference about the reported } \\
\text { study, seeking information about sample, sample selection, and population that } \\
\text { needs to be conveyed to make sense of generalizability of the reported findings }\end{array}$ \\
\hline & Proposing alternatives & $\begin{array}{l}\text { Suggesting alternatives regarding sampling with the consideration of } \\
\text { advantages and disadvantages of each alternative and considering alternative } \\
\text { sample sizes to draw proper conclusions, formulating alternatives of the } \\
\text { research design for reported study when background information is missing }\end{array}$ \\
\hline & Drawing conclusions & $\begin{array}{l}\text { Educing new reasonable verbal or numerical conclusions by using relevant } \\
\text { information about the reported study, reaching new proportions or calculations } \\
\text { from the probabilistic statements or percentages, making inferences about } \\
\text { reported study (e.g., generalizability) with the consideration of relevant } \\
\text { statistical information (e.g., representativeness of the sample, sample size, } \\
\text { random sampling) }\end{array}$ \\
\hline \multirow[b]{2}{*}{ Critiquing } & $\begin{array}{l}\text { Detecting misleading } \\
\text { information }\end{array}$ & $\begin{array}{l}\text { Detecting conflicting information or author's overgeneralization, considering } \\
\text { all aspects of conclusions of the reported study rather than just considering one } \\
\text { side of them, interrogating how the data of reported study is collected, possible } \\
\text { bias in measurement, recognizing the statements or reported statistics in a } \\
\text { given context which contradict with each other }\end{array}$ \\
\hline & $\begin{array}{l}\text { Recognizing factors of } \\
\text { credibility }\end{array}$ & $\begin{array}{l}\text { Paying attention to crucial concepts of statistics (e.g., sample size, } \\
\text { representativeness of sample, sampling, chance variability, inference from } \\
\text { sample to population) to judge the credibility of the findings, considering } \\
\text { critical factors concerning generalization of findings in the article (e.g., } \\
\text { random sampling, sample size, research design, confounding variables, sample } \\
\text { representativeness) }\end{array}$ \\
\hline \multirow[t]{2}{*}{ Self-Reflecting } & $\begin{array}{l}\text { Expressing own } \\
\text { strengths and } \\
\text { weaknesses }\end{array}$ & $\begin{array}{l}\text { Reading the article a few times to be sure if one did not notice something } \\
\text { important and questioning own personal beliefs or attitudes, expressing how } \\
\text { one makes assessment based on personal ideas and admitting own weaknesses } \\
\text { when one critiques the reliability of the results or conclusions in the article }\end{array}$ \\
\hline & $\begin{array}{l}\text { Making corrections or } \\
\text { revisions }\end{array}$ & $\begin{array}{l}\text { Correcting own mistakes after examining own thinking process and looking } \\
\text { back where one made mistakes or has inadequacies, making corrections in } \\
\text { calculations or interpretations }\end{array}$ \\
\hline
\end{tabular}




\section{Organization of Statistical Information in the Newspaper Article}

In this study, we organized participants' responses about statistical information in the newspaper article at three broad dimensions: Base of reported findings, reported findings, generalizability of reported findings in the newspaper article. The first, base of reported findings, includes information about the origin of reported research in the newspaper article. In his study Gal (2002) explained in the categories of "knowing why data are needed and how data can be produced" and "knowing how statistical conclusions or inferences are reached." On the basis of the categories in the Gal's model, we described the base of reported findings in the context of media texts as the background of the study including sampling process, data collection and data analysis processes, and report of findings. Background of the study mentioned in the newspaper article was not explicitly given, as in most the other articles. The second dimension of reported findings in the newspaper article refers to the descriptive or summary statistics such as percentages, mean, graphs and tables. As Gal (2002) and Watson (2006) explained, basic notions in statistics and probability include concepts such as average, chance, or representation of data in tables or charts in the context of statistical literacy. Newspaper articles mostly reports such descriptive information about research study. The last dimension is related to generalization of the findings reported in the newspaper article. This dimension mostly emerged from the data. In his study Gal (2002) also suggested adults at least intuitively make connections between how data is produced and how statistical conclusions are made and generalized. In this study, generalizability of reported findings refers to intuitively making sense of the extent to which reported findings are generalizable to the population or other similar contexts and identify crucial factors related to generalization such as sampling, sample size, sample representativeness, confounding variables, confidence interval, and design of the study.

\section{FINDINGS}

Findings regarding participants' critical thinking processes were organized under three headings of statistical information conveyed in the newspaper article: Critical thinking concerning (1) bases of reported findings, (2) reported findings, and (3) generalizability of reported findings.

\section{Critical Thinking about the Bases of Reported Findings in the Newspaper Article}

This section presents participants' critical thinking processes about the bases of the reported findings in the newspaper article. Base of the reported findings is regarded as background information of the study such as sampling, data collection and analysis process, and how results are interpreted and reported. Some of this information is not explicitly conveyed in the newspaper article.

Regarding sampling process, only one of the participants (Ali) mentioned the role of sample and its representativeness while judging the credibility of the study in the article. The other participants only stated the sample size of the reported study as it was written in the newspaper article (203 women and 203 men, or 406 people). Ali, at least intuitively, questioned how the sample size could have a role in making inferences from the sample to population. During this process, he proposed to consider the samples with different sizes such as 20 couples and 2000 people. He considered strengths and drawbacks of each sample size to make accurate inferences from the study:

203 couples, actually, the number is good. It gives considerable information, that is, it is neither 1 nor 2. Well, if this study had been conducted with 20 couples, the answers would not have been all that good, the extreme properties of those 20 people would have emerged. As the sample size increases, the power of the representativeness of the sample also increases. If this research had been conducted with 2000 people, we would state that it was more generalizable and more accurate. 
Participants' thinking process about data collection revealed that all participants concentrated on the what was measured in the questionnaire and what kind of questions were asked to the participants of reported study in the newspaper article, which is reported as the following statement: "Researchers at Virginia Commonwealth University in Richmond gave confidential questionnaires to 203 young couples, asking them whether they had ever strayed, and they suspected or knew their partner had.". Although two participants just restated the questions, other two participants attempted to clarify their meanings. Meltem, for example, clarified one of the questions in the questionnaire, "whether they [subjects in the reported study] had ever strayed". She stated as "I thought that it was a question about past relationship. The article could have just said like this: the young couple could have been informed that this study was about their current relationship." In order to clarify its meaning, she added the expression of current relationship to the question of "have you ever cheated" and removed the ambiguity in the question. Moreover, Ali attempted to critique a possible bias in data collection process based on a statement in the article, "29 per cent of men admitted that they had cheated compared with 18.5 per cent of women". He argued that subjects of the reported study might give deceptive information about their cheating situation by stating "Are men better confessors or do men cheat [their partners] more? It is unclear. Some might cheat [their partners] and says they didn't [cheat]; that's why, I think this may not give an idea about who cheat more."

Another finding related to the bases of reported finding was that all participants attempted to comprehend data analysis process of the reported study by reconsidering how data could be organized through categories. They intuitively identified variables of gender (women and men) and cheating (their predictions on partners' cheating and real situation on cheating) even though they did not explicitly used the term of variable. They suggested to compare the prediction and real situation. It was only İrem who reflect more comprehensive thinking process regarding data analysis of the reported study. While thinking about the statement of "Eighty per cent of women's inferences about fidelity or infidelity were correct, but men were even better, accurate 94 per cent of the time.", she constructed a table that shows the possible categories in the reported study in order to comprehend data analysis process of the study (Figure 1).



Figure 1. İrem's categorization of variables (gender, fidelity and infidelity inferences) to illustrate data analysis

The last main finding was about how the results in the article were reached and reported. Participants initially did not have any concern about the results reported in the newspaper, which conveys information about only women and men's correct inferences about their partners' cheating situation. They just restated the reported results in the article. Then, they made an effort to judge the results of the study in the newspaper article when they were particularly asked to critique the results. However, they mostly made subjective judgments. For example, Melek reflected on her thinking process while reading the media text. She expressed how she evaluated the results reported in the article stating "When thinking about the article, I think I'm adding my opinions a little. I'm looking at the claims made at the beginning and the numbers below, I'm comparing them. Even if I am not doing calculations... If it fits my line of thought, I believe it more." During this process she compared the differences between results that are represented as numerical values of $80 \%$ and $94 \%$, and $75 \%$ and $41 \%$ in the newspaper article and related them with the claim of the article. On the other hand, İrem was more critical about the results in the reported study after she constructed tables that organize the raw data (Figure 2). She realized the role of sample size in each category on determining credibility of 
the results besides whole sample size. To illustrate, she compared the number of subjects in each category and realized sample sizes (139 and 163), in the categories of women/men right inferences when their partners did not cheat them, were higher than the other categories. She stated as follows "If the number of people who are cheating had been higher than $29 \%$, the ratio of $41 \%$ would change possibly...there are much more people in the category of "women/men not cheating and their partner inferences right".

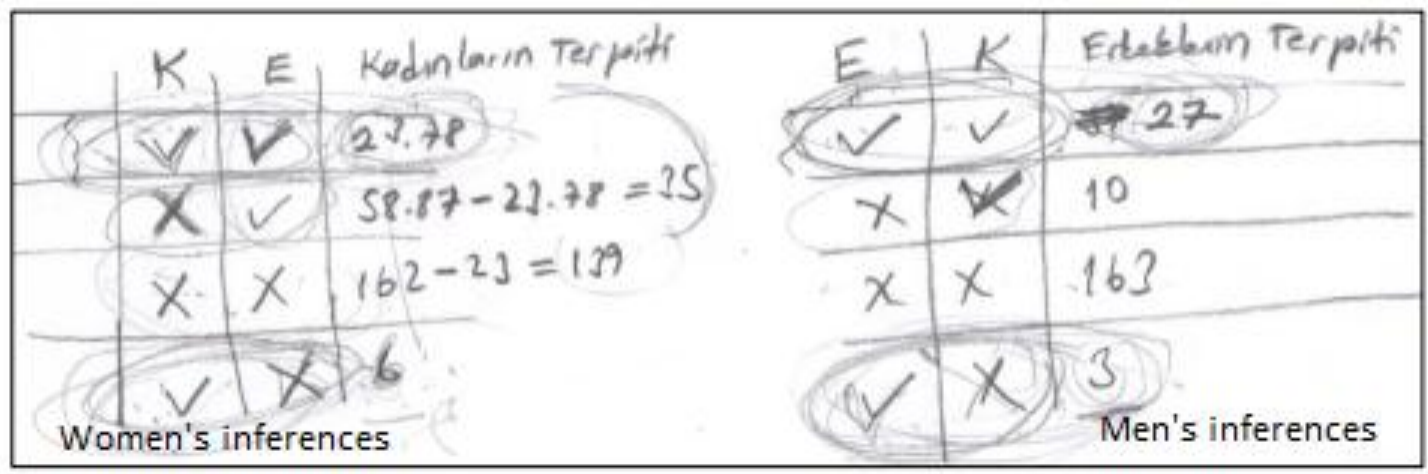

Figure 2. İrem's organization of the findings in the article through tables

To summary, participants made use of several interrelated critical thinking processes. They mostly comprehended and critiqued information that is already given in the newspaper article rather than missing information in the article, and also reflected on their own thinking processes. In fact, the newspaper did not provide complete information regarding reported study (e.g. how data were analyzed, reliability of the results, all findings emerged from the survey). The participants mostly did not question the missing information (women and men's wrong inferences about their partners' cheating) in the article.

\section{Critical Thinking about the Reported Findings in the Newspaper Article}

This part presents participants' critical thinking concerning four probabilistic statements in the newspaper article (Table 1), which involve descriptive or summary statistics such as percentages. Analysis of participants' thinking processes about reported statistics indicated that students attempted to comprehend the meanings of these statements, made connections between them to comprehend their meanings, inferred new conclusions from the statements that were not stated in the article, and during these processes they reread the article to make sure whether they understood the statements correctly (self-reflecting). There are four main findings that arise from this study.

The first main finding is related to Statement 1, which conveys information about the number of men and women who admit they were cheating their partners. Participants tried to comprehend the meaning of the Statement 1. Three of them restated it with different words on the basis of their calculations. They calculated the number of men and women who admit they were cheating by making link with another sentence in the article which gives information how many men and women participated to the reported study (203 couples). That is, they restated the Statement 1: "The results, published in New Scientist, show 29 per cent of men admitted they had cheated compared with 18.5 per cent of women". Melek, for example, clarified the meaning of Statement 1 through proportional reasoning (Figure 3). She explained as follows "There are 59 men and 38 women who admit they cheated on their partners". 


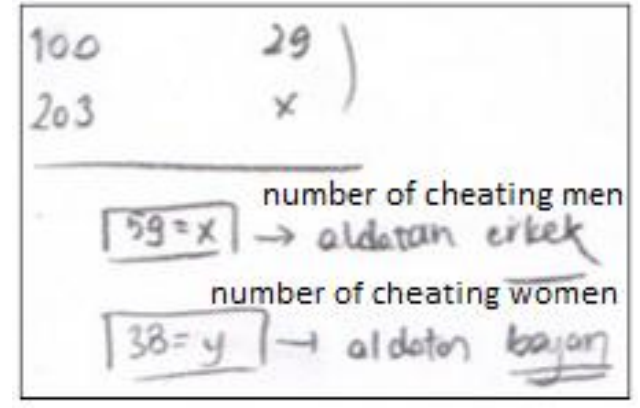

Figure 3. Melek's clarification of the meaning of Statement 1 through proportional reasoning

The second main finding is related to Statement 2 and Statement 3, which are closely related with each other and require to understand the concept of percentage as a representation of likelihood in context of cheating. All participants tried to cope with clarification of these two statements to make sense them. For example, Melek had difficulty comprehending the Statement 2 and Statement 3 when she firstly read the article. She could not identify the difference between two statements, stating "I could not understand these last two statistics (reads the last two paragraphs of the article). I think the meanings of the statements are the same. They are stated in the same way but with different values. Maybe there is a conflict here." In a similar way, İrem had also trouble in comprehending the meanings of two statements when she firstly read them as stating "Are they different? I don't know. I did not understand the concept of fidelity". In further process, she had still confusions about the fidelity, but this time she attempted to solve the problem of uncertainty in its meaning when she was asked to specifically think about Statement 2 . She questioned what infidelity and fidelity concepts mean:

I think I don't know the meaning of the concept 'fidelity'. I can't distinguish these two conditions [Statement 2 and Statement 3]. I think predicting [fidelity] correctly means when they say that they don't think their partner cheated on them, actually they [their partner] hadn't; and predicting infidelity correctly means when they say that their partner definitely must have cheated on them, their partner had done so.

İrem's thinking process became more sophisticated compared to that of Melek since she generated an idea about the meaning of the key terms in two statements and after that, she restated the Statement 2 numerically through proportional reasoning. She found how many men/women predict their partner's fidelity or infidelity correctly as in the following: "162 women predicted correctly whether or not their partner cheated on them. And I understood that 190 men accurately predicted whether their partner cheated on them." This thinking process indicates that İrem developed her clarification of Statement 2. However, she still had trouble in distinguishing the meaning of two statements. She could develop an idea about their differences when she was asked to specifically think about the Statement 3. She revised the Statement 3 by using numbers on the basis of certain calculations. However, she at first glance could not identify the conditional event of infidelity in the conditional statement of Statement 3: "Men were more likely to catch out a cheating partner, picking up on 75 per cent of the reported infidelities compared with 41 per cent discovered by women". In other words, she made calculations on the basis of all women and men rather the number of women and men cheating on their partners.

41 percent of 203 couples; so 83 women detected that their partner cheated on them. But there is something like this as well; 29 people admitted they had cheated their partners. I wonder whether $75 \%$ of $\% 29$ noticed cheating (reads the last paragraph again). According to the answers given, men noticed $75 \%$ of the cheatings done by their partners. I mean, it seems that $75 \%$ of cheating partners were noticed; but I made a mistake because I took 203 as a base.

For a while she recognized the Statement 1 that gives information about the number of men/women cheating and made a connection between Statement 1 and Statement 3 that are two closely related statements. In the process of examining connection between them, she revised the statements in the 
article and reread them to make sure that she did not overlook any crucial information in the article. After reading the article again, she realized her mistake and realized the conditional event in the Statement 3. This process provides an evidence of her self-reflecting process by means of which she monitored her thinking process and made corrections in calculations regarding conditional probability. Interestingly other two participants (Ali and Melek) had a similar cyclic thinking process. At first glance they could not realize the condition in the Statement 3 as well. During this process, none of the participants explicitly express the term of conditional probability.

An important finding raised from this cyclic thinking process was that two prospective teachers created a table (İrem) and a diagram (Ali) to organize the reported findings through process the processes of comprehending and examining links between the statements in the article (e.g. comprehending the Statement 3 by making use of information in the Statement 1). Thus, it seemed that they could go further and draw new conclusions that are not stated in the article (e.g., percentage of men/women's wrong inferences about fidelity or infidelity, percentage of men/women wrong inferences about their partners' infidelity). For example, Ali expressed new inferences about the article in a diagram (Figure 4). It was also represented by the researchers in two-way tables to see what kind of inferences Ali made (Table 3). On the other hand, other two participants (Meltem and Melek) reached inaccurate conclusions or could not make further inferences.

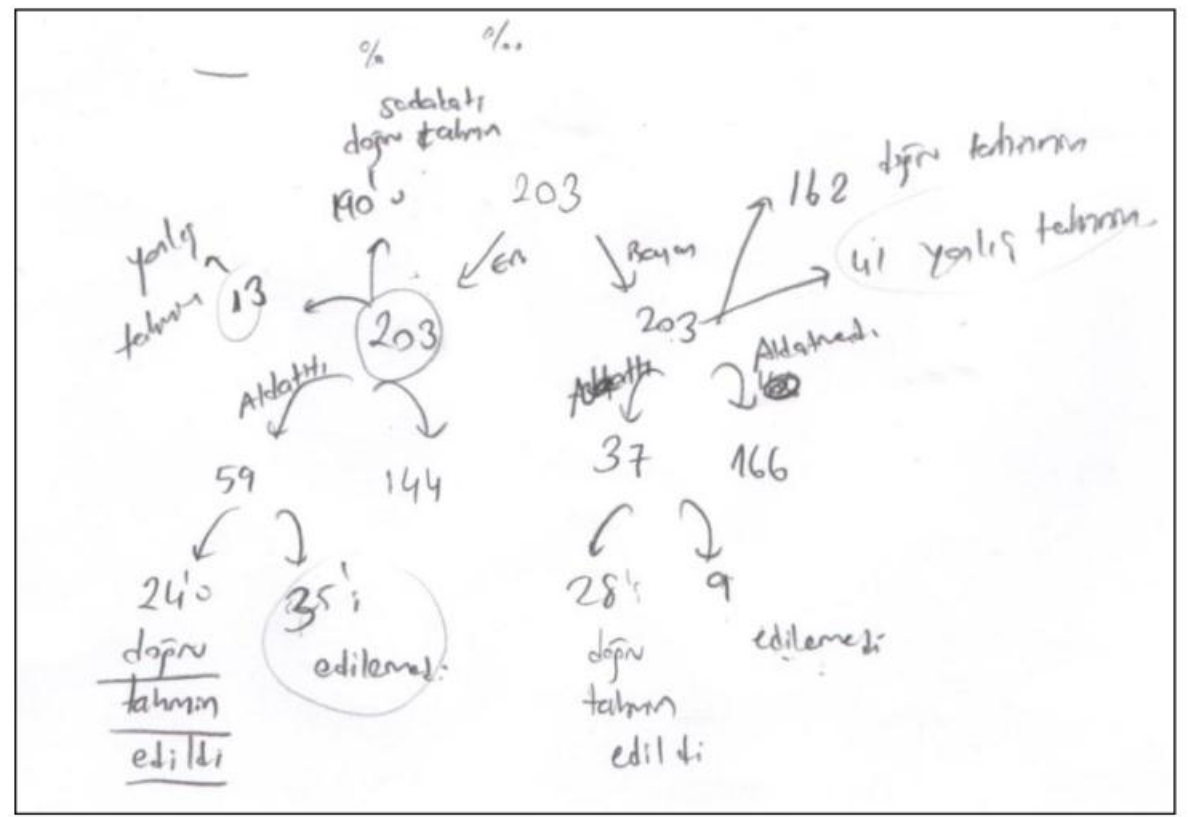

Figure 4. Ali's construction of a diagram like a tree diagram that show all possibilities

Table 3.

Male and females' inferences if their partners are cheating or not cheating in real life

\begin{tabular}{lllll}
\hline \multirow{2}{*}{ Male } & \multicolumn{3}{l}{ Partners' Cheating Situation in Real Life } \\
\cline { 3 - 5 } & & Cheating & Not Cheating & Total \\
\hline \multirow{3}{*}{ Female } & Right Inferences & 28 & - & 190 \\
& Wrong Inferences & 9 & 4 & 13 \\
& Total & 37 & 166 & 203 \\
\hline \multirow{2}{*}{ Right Inferences } & 24 & - & 162 \\
& Wrong Inferences & 35 & 6 & 41 \\
& Total & 59 & 144 & 203 \\
\hline
\end{tabular}

Note: Table was constructed by the researchers on the basis of Ali's diagram and his expressions. 
The last main finding was related to Statement 4, which is a verbal statement related to the concept of conditional probability. This statement involves misleading information about the reported study. One would interpret the statement of "They [men] are more likely to suspect infidelities that do not exist" in the article as "the probability of males' wrong inferences if their partners do not cheat is more than the probability of females' wrong inference if their partners do not cheat". However, there is not a consistency between author's argument and the calculations made based on the numbers and percentages in the article. When the following calculations are made (Watson, 2011), it is found that female are more likely to suspect infidelities that do not exist, which uncover the misleading information in the Statement 4.

$$
\begin{aligned}
& P(\text { Male wrong inference/Female not cheating })=3 / 165=1.8 \% \\
& P(\text { Female wrong inference/Male not cheating })=6 / 144=4.2 \%
\end{aligned}
$$

All of the participants overlooked this misleading information and could not detect it. However, only two (Ali and İrem) participants were worried about its meaning and attempted to criticize it. For example, in her critiquing process İrem had still confusions about the meaning of the verb of "suspect" and attempted to clarify its meaning. She proposed two alternative meanings for "being suspicious": (1) claiming his/her partner is cheating regardless of the fact that the partner is cheating or not cheating (2) claiming his/her partner is cheating; in fact, their partners are not cheating. On the basis of the second meaning, she made calculations and decided that Statement 4 conveys wrong information. She justified his thinking as stating "If we think the second meaning that I believe in, women are more suspicious. That is, women are suspicious unnecessarily. I think it [Statement 4] is wrong. For men, 1.4\% [3/203] and for women, 2.8\% [6/203]." Even though she thought the second meaning of the word is so meaningful that it fit with the meaning of Statement 4 and attempted to critique the credibility of Statement 4, she drew inaccurate conclusions by making use of relevant information in the table that she had constructed before (see Figure 2). She did not recognize the condition in the verbal statement of condition probability (the condition of men/women who are not cheating their partners). Instead she made calculations on the basis of the number of all participants (203) in the reported study.

In summary, there are four major findings regarding reported statistics (percentages and probabilistic statements): prospective mathematics teachers (1) had confusions about the meaning of the words or statements and making connections between statements; (2) had difficulty in understanding the meanings of the conditional probability statements and detecting conditional events in the statements; (3) reflected interrelated and cyclic process of critical thinking, particularly in conditional probability statements. This process was not so easy for prospective teachers, which required them to rethink about the meanings of words, review their calculations, reread the article, and correct their misunderstandings.

\section{Critical Thinking about the Generalizability of the Reported Findings in the Newspaper Article}

This part presents participants' thoughts about generalizability of reported findings, which requires at least intuitively to comprehend the extent to which reported findings can be generalizable to the population or other similar contexts. In the process of interviewing, participants were asked to think about to what extent the findings of the reported study could be generalizable. During this process, all of them had a tendency to critique the reported findings by recognizing several factors to determine generalizability of the reported study.

They focused on a variety of factors such as sample size (Ali, Meltem), background information about sample (residences, duration of marriage) (Ali, İrem), and sampling variability (İrem), confounding variables (İrem) and cultural factors (Ali, Melek). During critiquing process, two of the participants (İrem and Ali) differed from others since they searched for additional information (where participants 
live, duration of marriage) that should have been explained in the newspaper article to make critiques about findings' generalizability.

Ali, for example, focused on the factors of sample size, how the sample is selected, and cultural factors to criticize if the findings of the study would be generalizable to a different culture. The following statements of Ali indicate that he firstly examined any evidence of sample's residence. Besides he proposed alternatives for conducting the study with more people (sample size) and people with different characteristics to make it more generalizable even though he did not reflect on the population of the reported study. It also seemed that he perceived the generalizability as getting similar results at different cultures such as Turkey. Therefore, he thought that the study is not generalizable to the context of Turkey and claimed the findings do not match with the context of Turkey based on his personal ideas.

Well, where was the research conducted? It hasn't been mentioned. The researchers did not mention from where they selected the couples. Did they choose them from the same place where the research was conducted? Maybe it is unique to that region. If this research had been conducted with more effort, with many more participants having different characteristics, I mean if they had conducted on many places, it would have been more reliable. So, I think we cannot generalize it to Turkey.

Similarly, İrem thought that this study is not generalizable. She paid attention to the factors of sample size and properties of sample in order to criticize the generalizability of the reported findings, as shown below. In the critiquing process, she examined any evidence regarding sample characteristics such as their residencies or countries and the duration of their marriage in order to make a reasonable decision about the generalizability of the reported findings.

Well, I don't know if 203 couples are enough. I don't think it can be generalized. My opinion, you can't imagine something big from a small sample. If I ask each of the 203 men or if I ask 58 men, in this case, will women predict only 29 percent of 58 men correctly? It seems that it will not be correct all the time. You know, different results will be obtained from different samples; well, here the 203 couples don't have any characteristic features anyway. I mean, where do they live, in which country, I don't know how long they have been married; maybe there are many influential factors. It has only mentioned that they are young couples.

During this process, it seemed that she intuitively had a sense of sample variability even though she did not express it in statistical terms. In other words, she seemed to intuitively appreciate the variability among the different samples chosen from the same population. However, she was still in the deterministic thinking process and was not sure if the sample size is large enough, stating "You can't imagine something big from a small sample".

Compared to Ali and İrem's thinking process, Meltem thought the reported study was generalizable. She supported her claim by comparing sample size with two alternative sample sizes (30 and 100) and concluded sample size is enough to make generalization, stating as "203 is actually good number, in statistics when we, for example, carry out a study, we say it's a good result when it is over 30 or 100. Well, compared with that, 203 is good. It can be generalized because everything is clear."

In summary, participants tried to critique the generalizability of the reported findings. Two of the participants (Ali and İrem) were more critical about generalizability and considered several factors (e.g., sample size, sample variability, sample characteristics concerning different cultures) and did not make immediate decisions about the generalizability. They also sought for background information to decide if it was generalizable. However, none of the participants reflected on the population of the study, random sampling, and representativeness of the sample concerning population while thinking about generalization from the sample in the reported study. 


\section{DISCUSSION AND CONCLUSION}

This study examined prospective mathematics teachers' critical thinking processes when they were asked to read a scientific research reported in a media text. The analysis of prospective mathematics teachers' thinking process indicated that they made use of a variety of critical thinking processes ranging from comprehending to self-reflecting. This study also provided clues about related nature of critical thinking processes and their role in critical reading of media texts, which is regarded as the most easily accessible tool conveying statistical information to the public (Lin, 2014; Watson, 1995). For example, when prospective mathematics teachers were comprehending information in the media text, they made connections between statements in the article and had a tendency to question the meanings of the words or credibility of the statements. While inferring new conclusions/findings that were not stated in the article, two students (Ali and İrem) overviewed their thinking process and reread the article to check whether they understood the meaning of the statements correctly and made reasonable inference on the basis of their mathematical knowledge (e.g., proportional reasoning). This finding supports that skills of critical thinking are interrelated and also some skills could be executed by the use of other skills (Facione, 1990). In the statistics education context this finding implies that comprehending statistical information or making connections are as crucial as evaluating statistical claims in the newspaper articles. Interconnected use of critical thinking skills might tap use of different skills such as inferring ideas or critiquing information. In addition, as a remarkable finding, some skills of critical thinking became precondition for the use of other skills. For example, prospective teachers who could not clarify the meaning of the terms in the article and make connections between statements could not make further inferences from the article (Facione, 1990). In the current study, the newspaper article was originally presented to the participants without making any changes or manipulations. It might have crucial factor to elicit such an interrelated nature of critical thinking and its components in the context of statistics and probability.

The second major conclusion was that participants mostly made comments on existing information rather than missing information in the article (e.g., sampling, data analysis, data collection, missing findings). Newspaper articles might report lack of information or biased information about the reported study (McClune \& Jarman, 2012). Thinking beyond the context, e.g. reading not only the existing information but also the missing information, is a crucial ability for being critical thinker while reading such media articles (Gal, 2002; Watson, 2006). In the current study, most of the prospective mathematics teachers focused on the sample size, which was the only information regarding sampling presented in the article. This finding was parallel with informal level of statistical literacy proposed by Watson and Callingham (2003) in which students consider a single aspect of statistical concepts. In addition, there were not sufficient information about data analysis and data collection processes in the article. Prospective teachers did not make sufficient comments particularly on data analysis. Newspaper articles does not often provide enough information about background of the study and this might lead to make hypothetical comments regarding original study and to have difficulty in discriminating the critique of the reported study from actual study (Budgett \& Pfannkuch, 2010). Thus, prospective teachers in the current study might have had difficulty in making comments about actual study that does not exist in article. To make sound arguments about this finding, there is need for further studies. Such a problem in the newspaper article suggests the use of these kind of articles with the support of original research in the statistics education courses (Budgett \& Pfannkuch, 2010; Gelman \& Nolan, 2002). In the further studies, prospective teachers' critical thinking would be analyzed and compared in newspaper articles with different characteristics (with detailed information, without sufficient information) to decide what kind of newspaper articles could be used in the statistics education courses for mathematics teachers.

The third major conclusion was that during their first reading of the article, prospective mathematics teachers did not analyze critically the reported statistics (percentages, probabilistic statements) in the article and did not make inferences about them. They just restated what the article had already 
reported. When they were asked to think about the meanings about the probabilistic statements through probing questions, it was revealed that prospective mathematics teachers had difficulty in identifying conditional events in the statements and they did not reflect on statistical concept (conditional probability) behind these statements even though they were taught about this concept in statistics education courses. Participants' difficulty in identifying conditional events is consistent with the findings of previous studies on conditional probability (Carnell, 1997; Falk, 1986; Stohl, 2005). This finding also suggests training of prospective mathematics teachers on learning and teaching statistics in real life contexts such as media article, which is particularly regarded as a natural way to introduce conditional probability concept (Watson, 1995). Moreover, prospective mathematics teachers who could use their mathematical and statistical knowledge (proportional reasoning, percentage, and creating two way-table or tree diagram) and comprehend statements effectively identified conditional events intuitively even though they did not realize them at first glance and use the term of conditional probability formally. This finding supports the previous studies on contingency table (Watson \& Callingham, 2014) and tree-diagram (Böcherer-Linder, Eichler, \& Vogel, 2017) including natural frequency that helped to comprehend conditional probability concept and discriminate the conditional events. Besides the use of displays in comprehending conditional probability concept, this study suggests statistics courses in mathematics teacher education encourage teachers to transfer of their mathematical and statistical knowledge to a variety of topics of media articles (e.g., health, politics, education, social life context) by giving enough time to think.

The fourth major conclusion was that participants conceptualized the generalization of findings as generalization from the sample to population or generalization from one context to another context. This finding is important to understand to what extent prospective mathematics teachers believe to the reported study and make decisions in their life. Prospective mathematics teachers critiqued the generalizability of the reported study based on a few statistical concepts (sample size and characteristics of the sample) or based on their personal ideas. This finding brings about the need for training of prospective mathematics teachers to analyze media texts reporting statistical research in a more comprehensive way. On the other hand, this study calls for training of mathematics teachers in statistics education to appreciate the nature of statistics and understand its difference from mathematics (Gattuso \& Ottaviani, 2011) and design of statistics courses for prospective teachers (Watson \& Moritz, 2002). The reason such a need is that one of the prospective mathematics teachers with a minor on mathematics department did not appreciate uncertain generalization from sample to population as stating "you can't imagine something big from small sample" when she was asked to think about the generalizability of the study. This finding could be interpreted as an evidence of which mathematics teachers could think the nature of statistics like mathematics. On the other hand, it might also be related to imbalance between critical thinking and statistical thinking as discussed by Kuntze, Aizikovitsh-Udi, and Clarke (2017). The prospective mathematics teacher's extreme criticism might have impeded their understanding of the nature of statistics and appreciation of uncertain generalization from sample to population.

The researchers and teachers who wants to reimplement this study in other contexts should consider several important points. One of the major points is that the prospective mathematics teachers in the current study were selected as having tendency to criticize the media article and took courses on statistics and research at their undergraduate program. In other words, they were already taught about key statistical concepts such as sample, sampling, variability, inference, and probability in the undergraduate program. Even so, they had some struggles in critical evaluation of media article as discussed above. However, the statistics courses in the undergraduate program did not involve use of newspaper article and interpreting statistical information in such contexts. Rather, it was based on teaching of concepts theoretically. Researchers and teachers should also consider that participants were given enough time to think about newspaper article and it was originally presented to the readers without making any changes on it. There was not time limitation for reading article and making judgments about the article. Lastly, this study presents the findings about prospective mathematics teachers' critical thinking processes related to one media text, which includes probabilistic statements about a social life context. Focusing on a particular concept and media article allowed in-depth 
analysis by monitoring the flow of prospective teachers' thoughts. The reason of such a focus was also to present specific examples of blended theoretical frameworks of critical thinking and statistical literacy since the use of this framework is new and was adapted in the current study. Although focusing on one text provide in-depth examination of thinking processes, it would be also a limitation of the study. Thus, the findings of this study should be interpreted within its limitations such as the number of participants and its focus on an article including conditional probability concept in a social life context.

In conclusion, unique contribution of this study is twofold. First, this study showed that prospective mathematics teachers were in the processes of a variety of critical thinking processes ranging from comprehending to self-reflecting and each process of critical thinking has a crucial role to be critical thinkers in reading statistical information regarding a scientific research. Even though prospective mathematics teachers had completed statistics courses in the undergraduate education, they seemed to have difficulty in transferring their knowledge of statistics to the context of media texts and in making judgments by relating relevant concepts of statistics with a critical stance. Statistics has been often taught theoretically (Batanero \& Diaz, 2010). The investigation of a media text and its adaptation to the statistics education allows researchers and teachers to relate statistics with daily life, which would, in turn, help to design and integrate such media tasks with the statistics courses in teacher education programs.

Secondly, this study contributes to the literature in terms of theoretical aspects. It does not only involve investigation of critical thinking processes in a particular context; but also, adaptation of critical thinking framework proposed by Facione (1990) to the context of statistics, which has been developed based on quantitative studies. Critical thinking has been often emphasized by the researchers in learning and teaching of statistical literacy. However, researchers have not paid attention to the elaboration of the concept of critical thinking in the context of statistics (Kuntze, Aizikovitsh-Udi, \& Clarke, 2017). This study provides detailed exploration of critical thinking and its indicators in the context of statistical literacy through suggesting blended framework of critical thinking and statistical literacy. It has theoretical significance since it shows a case of how this framework works in the statistical literacy context. It would allow researchers to refine conceptualization of critical thinking by exploring interaction between critical thinking and statistical literacy and also to assess students' and teachers' critical thinking processes in the statistics education context. In further studies it could be elaborated and developed by using different topics of media texts (e.g., health, politics) including statistical studies with different methods (e.g., experimental, survey, correlational) and with data displays such as table and graphs.

\section{Acknowledgement}

This study was presented at the Ninth Congress of the European Society for Research in Mathematics Education (CERME 9). It is also a part of the first author's master thesis and it was approved by the Human Research Ethics Committee.

\section{REFERENCES}

Aizikovitsh-Udi, E., Kuntze, S., \& Clarke, D. (2016). Connections between statistical thinking and critical thinking: A case study. In D. Ben-Zvi \& K. Makar (Eds.), The teaching and learning of statistics (pp. 8394). Cham, Switzerland: Springer. DOI:10.1007/978-3-319-23470-0_8

Australian Education Council (1991). A national statement on mathematics for Australian schools. Carlton, Victoria: Curriculum Corporation.

Batanero, C., Burrill, G., \& Reading, C. (2011). Overview: Challenges for teaching statistics in school mathematics and preparing mathematics teachers. In C. Batanero, G. Burrill, \& C. Reading (Eds.), 
Teaching Statistics in School Mathematics. Challenges for Teaching and Teacher Education: AJoint ISMI/IASE Study (pp. 407-418). New York: Springer. DOI: 10.1007/978-94-007-1131-0

Batanero, C., \& Díaz, C. (2010). Training teachers to teach statistics: what can we learn from research? Statistique et enseignement, 1(1), 5-20.

Ben-Zvi, D., \& Garfield, J. (2008). Introducing the emerging discipline of statistics education. School Science and Mathematics, 108(8), 355-361. DOI: 10.1111/j.1949-8594.2008.tb17850.x

Böcherer-Linder, K., Eichler, A., \& Vogel, M. (2017). The impact of visualization on flexible Bayesian reasoning. Avances de investigación en educación matemática, 11, 25-46. DOI: 10.35763/aiem.v1i11.169

Budgett, S., \& Pfannkuch, M. (2010). Assessing students' statistical literacy. In P. Bidgood, N. Hunt, \& F. Jolliffe (Eds.), Assessment methods in statistical education: An international perspective (pp. 103-121). Chichester, UK: Wiley. DOI: 10.1002/9780470710470.ch9

Burrill, G., \& Biehler, R. (2011). Fundamental statistical ideas in the school curriculum and in training teachers. In C. Batanero, G. Burrill, \& C. Reading (Eds.), Teaching statistics in school mathematics: Challenges for teaching and teacher education (A joint ICMI/IASE Study) (pp. 57-69). New York, NY: Springer. DOI: 10.1007/978-94-007-1131-0_10

Cantürk-Günhan, B., Bukova-Güzel, E. \& Özgür, Z. (2012). The prospective mathematics teachers' thought processes and views about using problem-based learning in statistics education. International Journal of Mathematical Education in Sciences and Technology, 43(2), 145-165. DOI: 10.1080/0020739X.2011.592611

Carnell, L. J. (1997). Characteristics of reasoning about conditional probability (Unpublished doctoral dissertation). University of North Carolina, Greensboro.

Cheat radar better tuned in men, study finds. (2008, October 30). The Mercury (Hobart, Tasmania), p. 3.

Chesler, J. (2015). Reading the News: The Statistical Preparation of Pre-Service Secondary Mathematics Teachers. Issues in the Undergraduate Mathematics Preparation of School Teachers, 1. Retrieved from https://eric.ed.gov/?id=EJ1061106

delMas, R. (2002). Statistical literacy, reasoning and learning: A commentary. Journal of Statistics Education, 10(3). Retrieved from https://www.tandfonline.com/doi/full/10.1080/10691898.2002.11910679. DOI: 10.1080/10691898.2002.11910679

Ennis, R. H. (1985). A logical basis for measuring critical thinking skills. Educational Leadership, 43(2), 44-48.

Ennis, R. H., \& Weir, E. E. (1985). The Ennis-Weir critical thinking essay test: An instrument for teaching and testing. Pacific Grove, CA: Midwest Publications.

Facione, P. A. (1990). Critical thinking: A statement of expert consensus for purposes of educational assessment and instruction. Research findings and recommendations (ERIC Document Reproduction Service No. ED315423). Retrieved from https://eric.ed.gov/?id=ED315423.

Facione, P. A. (2011). Think critically. New York: Pearson Education, Englewood Cliffs.

Falk, R. (1986). Conditional probabilities: Insights and difficulties. In R. Davidson \& J. Swift (Eds.), Proceedings of the Second International Conference on Teaching Statistics (pp. 292-297). Victoria, Canada: International Statistical Institute.

Gal, I. (2002). Adults' statistical literacy: Meaning, components, responsibilities. International Statistical Review, 70(1), 1-25. DOI: 10.1111/j.1751-5823.2002.tb00336.x

Gal, I. (2005). Towards "probability literacy" for all citizens: Building blocks and instructional dilemmas. In G. A. Jones (Ed.), Exploring probability in school. Challenges for teaching and learning (pp. 39-63). Dordrecht, The Netherlands: Kluwer. DOI: 10.1007/0-387-24530-8_3

Gattuso, L., \& Ottaviani, M. G. (2011). Complementing mathematical thinking and statistical thinking in school mathematics. In C. Batanero, G. Burrill \& C. Reading (Eds.), Teaching statistics in school mathematicsChallenges for teaching and teacher education: A Joint ICMI/IASE Study (pp. 121-132). Springer. DOI: 10.1007/978-94-007-1131-0_15

Gelman, A., \& Nolan, D. (2002). Teaching statistics: A bag of tricks. Oxford University Press. DOI: 10.1093/oso/9780198785699.001.0001

Gould, R. (2017). Data literacy is statistical literacy. Statistics Education Research Journal, 16(1), 22-25.

Halpern, D. F. (1998). Teaching critical thinking for transfer across domains. American Psychologist, 53(4), 449-455. DOI: 10.1037/0003-066X.53.4.449

Jacobs, H. (2010). Curriculum 21: Essential education for a changing world. Alexandria, VA: ASCD.

Jarman, R., \& McClune, B. (2007). Developing scientific literacy: Using news media in the classroom. England, Open University Press.

Kennedy, M., Fisher, M. B. \& Ennis, R. H. (1991). Critical thinking: Literature review and needed research. In L. Idol \& B. F. Jones (Eds.), Educational values and cognitive instruction: Implications for reform (pp. 11-40). Hillsdale, NJ: Erlbaum. DOI: https://doi.org/10.4324/9781315044392

Kuhn, D. (1999). A developmental model of critical thinking. Educational Researcher, 28(2), 16-25. DOI: 10.3102/0013189X028002016 
Kuntze, S., Aizikovitsh-Udi, E., \& Clarke, D. (2017). Hybrid task design: Connecting learning opportunities related to critical thinking and statistical thinking. ZDM, 49(6), 923-935. DOI: $10.1007 /$ s11858-017-08744

Lin, S. S. (2014). Science and non-science undergraduate students' critical thinking and argumentation performance in reading a science news report. International Journal of Science and Mathematics Education, 12(5), 1023-1046. DOI: 10.1007/s10763-013-9451-7

McClune, B. \& Jarman, R. (2012). Encouraging and equipping students to engage critically with science in the news: What can we learn from the literature? Studies in Science Education, 48(1), 1-49. DOI: $10.1080 / 03057267.2012 .655036$

McPeck, J. E. (1990). Critical thinking and subject specificity: A reply to Ennis. Educational Researcher, 19(4), 10-12. DOI: $10.3102 / 0013189 X 019004010$

Ministry of National Education (2018). Matematik Dersi Öğretim Programı (İlkokul ve Ortaokul 1-8. Sınıflar) [Teaching Program of Mathematics Course (Elementary and Middle School 1-8 Grades)]. Ankara. Retrieved from http://mufredat.meb.gov.tr/Dosyalar/201813017165445MATEMAT\%C4\%B0K\%20\%C3\%96\%C4\%9ERET\%C4\%B0M\%20PROGRAMI\%202018v.pdf.

Moore, D. S. (1998). Statistics among the liberal arts. Journal of the American Statistical Association, 93(444), 1253-1259. DOI: 10.1080/01621459.1998.10473786

National Council of Teachers of Mathematics (2000). Principles and standards for school mathematics. Reston, VA: NCTM.

Norris, S. P. \& Phillips, L. M. (2012). Reading science: How naive view of reading hinders so much else. In A. Zohar \& Y. J. Dori (Eds.), Metacognition in science education: Trends in current research (pp. 37-56). Dordrecht, The Netherlands: Springer. DOI: 10.1007/978-94-007-2132-6_3

Paul, R. (1984). Critical thinking: Fundamental for education in a free society. Educational Leadership, 42(1), 414.

Rumsey, D. J. (2002). Statistical literacy as a goal for introductory statistics courses. Journal of Statistics Education, 10(3). DOI: 10.1080/10691898.2002.11910678

Schield, M. (1999). Statistical literacy: Thinking critically about statistics. Of Significance, 1(1), 15-20. Retrieved from www.statlit.org/pdf/1999SchieldAPDU.pdf.

Schield, M. (2004). Information literacy, statistical literacy, data literacy. IASSIST quarterly, 28(2-3), 6-11. DOI: 10.29173/iq790

Siegel, H. (1988). Educating reason: Rationality, critical thinking, and education. New York: Routledge. DOI: 10.1177/027046769101100128

Stohl (2005). Probability in teacher education and development. In G. Jones (Ed.), Exploring probability in schools: Challenges for teaching and learning (pp. 345- 366). Dodrecht: Kluwer. DOI: 10.1007/0-38724530-8_15

ten Dam, G., \& Volman, M. (2004). Critical thinking as a citizenship competence: Teaching strategies. Learning and Instruction, 14(4), 359-379. DOI: 10.1016/j.learninstruc.2004.01.005

Utts, J. (2003). What educated citizens should know about statistics and probability. The American Statistician, 57(2), 74-79. DOI: 10.1198/0003130031630

Vieira, R. M., \& Tenreiro-Vieira, C. (2016). Fostering scientific literacy and critical thinking in elementary science education. International Journal of Science and Mathematics Education, 14(4), 659-680. DOI: 10.1007/s10763-014-9605-2

Wagner, T. (2014). The global achievement gap: Why even our best schools don't teach the new survival skills our children need and what we can do about it. New York: Basic Books.

Wallman, K. (1993). Enhancing statistical literacy: Enriching our society. Journal of the American Statistical Association, 88(421), 1-8. DOI: 10.1080/01621459.1993.10594283

Watson, J. M. (1995). Conditional probability: Its place in the mathematics curriculum. The Mathematics Teacher, 88(1), 12-17.

Watson, J. M. (1997). Assessing statistical literacy through the use of media surveys. In I. Gal \& J. Garfield (Eds.), The assessment challenge in statistics education (pp. 107-121). Amsterdam, The Netherlands: International Statistical Institute/ IOS Press.

Watson, J. M. (2006). Statistical literacy at school: Growth and goals. Mahwah, New Jersey: Lawrence Erlbaum Associates. DOI: 10.4324/9780203053898

Watson, J. M. (2011). Cheating partners, conditional probability and contingency tables. Teaching Statistics, 33(3), 66-70. DOI: 10.1111/j.1467-9639.2010.00421.x

Watson, J., \& Callingham, R. (2003). Statistical literacy: A complex hierarchical construct. Statistics Education Research Journal, 2(2), 3-46.

Watson, J., \& Callingham, R. (2014). Two-way tables: Issues at the heart of statistics and probability for students and teachers. Mathematical Thinking and Learning, 16(4), 254-284. DOI: $10.1080 / 10986065.2014 .953019$ 
Watson, J., Callingham, R., \& Nathan, E. (2009). Probing teachers' pedagogical content knowledge in statistics: "How will Tom get to school tomorrow?" In R. Hunter, B. Bicknell, \& T. Burgess (Eds.), Proceedings of the 32nd annual conference of the Mathematics Education Research Group of Australasia (Vol. 2, pp. 563-570). Adelaide: MERGA.

Watson, J. M., \& Moritz, J. (2002). Quantitative Literacy for pre-service teachers via the Internet. Mathematics Teachers Education and Development, 4(1), 42-55.

Watson, J., \& Nathan, E. (2010). Biased sampling and PCK: The case of the marijuana problem. In L. Sparrow, B. Kissane, \& C. Hurst (Eds.), Shaping the future of mathematics education. Proceedings of the $33^{\text {rd }}$ annual conference of the Mathematics Education Research Group of Australasia (Vol. 2, pp. 610-617). Fremantle, WA: MERGA.

Zhang, Q., \& Stephens, M. (2016). Teacher capacity as a key element of national curriculum reform in statistical thinking: A comparative study between Australia and China. In D. Ben-Zvi and M. Makar (Eds.), The Teaching and Learning of Statistics (pp. 301-313). Cham, Switzerland: Springer. DOI:10.1007/978-3319-23470-0_36 


\section{APPENDIX 1.}

\section{Cheat radar better tuned in men, study finds}

WOMEN beware. New research shows men are better at detecting a cheating partner than females, and they are more likely to suspect infidelities that do not exist.

A U.S study of heterosexual couples found men are more suspicious, but an Australian sex researcher says they are only more suspecting because they are more likely to cheat.

"What we have here is a clear case of the pot calling the kettle black," said Sydney therapist Rosie King.

Researchers at Virginia Commonwealth University in Richmond gave confidential questionnaires to 203 young couples, asking them whether they had ever strayed, and whether they suspected or knew their partner had.

The results, published in New Scientist, show 29 per cent of men admitted they had cheated compared with 18.5 per cent of women.

Researcher Paul Andrews said men were better at judging fidelity than women.

"Eighty per cent of women's inferences about fidelity or infidelity were correct, but men were even better, accurate 94 per cent of the time," Dr. Andrews said.

Men were more likely to catch out a cheating partner, picking up on 75 per cent of the reported infidelities compared with 41 per cent discovered by women.

AAP MERCURY-3 Thursday, October 30, 2008 


\section{TÜRKÇE GENIŞLETILMIŞ ÖZET}

Bilim ve teknolojideki hızlı ilerlemeye paralel olarak, 21. Yüzyılda ihtiyaç duyulan yeni beceriler ve okuryazarlık türleri birçok eğitimci tarafından ele alınmıştır. Bilgi toplumunda bireyler için önemli olan bu becerilerden biri, istatistiksel okuryazarlıktır (Gal, 2002; Gould, 2017). Bugün bireyler medyada çok çeşitli kaynaklardan bilgiye ulaşmaktadır ve bu bilgilerin çoğu istatiksel araştırmalardan bulgu ve sonuçlar içermektedir (Schield, 2004). Bireylerin medyadaki bu bilgileri kendi kanaatlerini oluşturmadan önce eleştirel olarak gözden geçirmeleri gerekir. Bu bağlamda, istatiksel okuryazarlığın, toplumda öne sürülen iddia ve argümanları sorgulayan ve etkili kararlar veren bir birey olmada önemli bir rolü vardır (Moore, 1998). Aksi takdirde, bireylerin, istatistiksel okuryazarlığa sahip olmadan çevrelerindeki olaylar hakkında sağlam fikirler geliştirmeleri zor olacaktır. Aynı zamanda, medyada yayınlanan bu bilimsel araştırmaların güçlü ya da sınırlı yanlarının farkına varılmasında eleştirel düşünmenin de önemli rol oynadığı vurgulanmıştır (Gal, 2002; Lin, 2014; Norris ve Phillips, 2012; Vieira ve Tenreiro-Vieira, 2016; Watson, 1997).

İstatistiksel okuryazarlık ve eleştirel düşünmenin önemine yönelik vurgulara rağmen, öğrencilerin çoğu medya haberlerinde yer alan bilimsel araştırmaları anlamlandıracak düzeyde istatistiksel ve matematiksel bilgiye sahip olmayıp, herhangi bir eleştiri yapmadan haberde verilen bilgilere inanma eğilimindedir (Watson, 2006). Öğrencileri toplumda eleştirel düşünen bireyler olarak yetiştirmek için atılacak ilk adım, geleceğin öğretmenleri ve toplumun birer vatandaşı olan öğretmen adaylarının eğitilmesidir. Eğer matematik öğretmenleri günlük yaşamda karşılaştıkları içerikleri okurken yeterince istatistiksel bilgiye ve eleştirel düşünceye sahip olmazsa bu durum öğrencilerin istatistiksel okuryazarlıklarının gelişimini engelleyebilir (Watson, Callingham ve Nathan, 2009). Bu yüzden öğretmenlerin istatistiğin günlük yaşam içeriklerinde kullanıma yönelik ve bu bağlamlarda öğrencilerin eleştirel düşünmesinin geliştirilmesi için pedagojik alan bilgisine sahip olmaları gerekmektedir. Fakat, ortaokul öğretmenlerinin istatiksel bilgileri günlük yaşama aktarmada zorluk yaşadıkları (Watson ve Nathan, 2010) ve medya haberlerinin sınıf içinde kullanımı konusunda yeterince özgüvene sahip olmadıkları ortaya çıkarılmıştır (Jarman ve McClune, 2007). Bu araştırmalar öğretmenlerin gazete haberi gibi günlük yaşam içeriklerini okurken derinlemesine bilişsel düşünme süreçlerinin incelemeye ihtiyaç olduğunu vurgulamaktadır. $\mathrm{Bu}$ araştırmalara ek olarak, Kuntze, Aizikovitsh-Udi ve Clarke (2017) hem istatiksel düşünme hem de eleştirel düşünmeyi hedefleyen etkinliklerin önemini vurgulayarak bu etkinliklerin tasarımına ihtiyaç olduğunu belirtmişlerdir.

Matematik öğretmeni adaylarının eleştirel düşünme süreçlerinin bir teorik çerçeve bağlamında incelenmesi bu amacı gerçekleştirmek için önemli bir adım olacağı düşünülmektedir. Bu bağlamda, bu araştırmada Facione (1990)'nin önermiş olduğu eleştirel düşünme teorik çerçevesini istatistiksel okuryazarlık bağlamına uyarlayarak, harmanlamış bir çerçeve ile şu araştırma sorusunun araştırılması hedeflenmiştir: "Ortaokul matematik öğretmeni adayları bir gazete haberinde yayınlanan bilimsel bir araştırmayı okurken nasıl eleştirel olarak düşünmektedir?"

$\mathrm{Bu}$ araştırma sorusuna yanıt aramak üzere, nitel araştırma yöntemlerinden biri olan durum çalışmasından yararlanılmıştır. Araştırmanın katılımcılarını bir devlet üniversitesinde öğrenim gören dört son sınıf matematik öğretmeni adayı oluşturmaktadır. Katılımcılar, 38 son sınıf matematik öğretmeni adayı arasından, bir gazete haberi ile ilgili sorulara verdikleri cevaplar doğrultusunda, (1) zengin veri sağlama potansiyellerine, (2) düşüncelerini geçerli matematiksel ifadelerle ifade etmelerine ve (3) haberde eleştirilecek kritik noktaları saptama eğilimlerine göre seçilmiştir. Katılımcılarla yapılan yarı yapılandırılmış görüşmeler bu çalışmanın veri toplama kaynaklarını oluşturmaktadır. $\mathrm{Bu}$ görüşmeler yaklaşık olarak 45 dakika sürmüştür. Katılımcılardan, Tazmanya Mercury tarafından yayınlanan (Ek 1), erkek ve kadınların sadakatleri üzerine yapılan bir bilimsel 
araştırma içeren gazete haberini (Watson, 2011) okumaları istenmiştir. Bu gazete haberi özellikle koşullu olasılık kavramı ile ilgili olmak üzere istatistiksel bir araştırmanın sonuçlarını içermektedir. $\mathrm{Bu}$ gazete haberi ile ilgili katılımcilara belirli sorular sorularak (örn., Bu gazete haberindeki araştırmacı veriyi nasıl toplamış olabilir? Yayınlanan bu bulguları nasıl değerlendiriyorsun? $\mathrm{Bu}$ bulguların genellenebilirliği hakkında ne düşünüyorsun?) veri toplanması hedeflenmiştir.

Katılımcılarla yapılan derinlemesine görüşmeler, Facione (1990) tarafından önerilen eleştirel düşünme teorik çerçevesinden yararlanılarak analiz edilmiştir. Bu teorik çerçeve istatistik eğitimine, istatistiksel okuryazarlık ile ilgili modellerle (Gal, 2002; Watson, 2006) ilişkilendirilerek adapte edilmiştir. $\mathrm{Bu}$ istatistiksel okuryazarlık modelleri çerçevesinde gazete haberindeki istatistiksel bilgi üç ana başlıkta (yayınlanan bulguların arka planı, yayınlanan bulgular ve yayınlanan bulguların genellenebilirliği) organize edilmiştir ve bu üç başlığa göre öğretmen adaylarının eleştirel düşünme süreçleri incelenmiştir. Yayınlanan bulguların arka planı (base of reported findings), haberde verilen bilimsel araştırmanın nasıl yürütüldüğü (örneklem seçimi, veri toplama ve analizi, bulgular ve yorumlanması) ile ilgili olup çoğunlukla gazete haberlerinde sınırlı olarak sunulmaktadır. Yayınlanan bulgular (reported findings) ise, gazete haberine yansitılan ve istatistiksel kavramlar (örn., yüzde, ortalama, olasılık) içeren ifadeler olarak tanımlanmıştır. Yayınlanan bulguların genellenebilirliği (generalizability of reported findings) ise yayınlanan bu bulguların örneklemden popülasyona ya da başka benzer bağlamlara ne derece aktarılabileceği ile ilgilidir. Eleştirel düşünme teorik çerçevesinde bazı değişiklikler yapılarak bu teorik çerçeve çalışmanın bağlamına uyarlanmıştır. Eleştirel düşünme süreçleri; anlama, bağlantı kurma, çıkarım yapma, eleştirme ve yansıtıcı düşünme olarak isimlendirilmiştir.

Verilerin analizi sonucunda üç temel bulguya rastlanılmıştır. İlk olarak, öğretmen adayları eleştirel düşünme süreçlerini iç içe geçecek şekilde kullanarak, gazetede verilmeyen eksik ifadelerden ziyade çoğunlukla gazetede var olan bilgileri anlamaya ve eleştirmeye çalışmıştır. Yayınlanan bulguların arka planı (örneklem seçimi, veri toplama ve analizi süreci, bulguların belirlenmesi ve yorumlanması) ile ilgili olarak sadece gazetede var olan bilgiler çerçevesinde yorum yapmışlardır. Gazetede örneklem büyüklüğü verildiği için, çoğunlukla örneklem büyüklügüne odaklanmışlardır. Diğer öne çıkan bulgu ise, yayınlanan istatistiksel bulgularla (yüzde ve olasılık ifadeleri) ilişkilidir. Öğretmen adayları koşullu olasılık kavramı içeren ifadeleri anlamaya ve bu sırada bu ifadeler arasında bağlantı kurmaya çalışmıştır. Ancak sözel olarak yayınlanan bu ifadeleri anlamada ve eleştirmede oldukça zorlanmışlardır. Bu süreç, kelimelerin anlamı netleştirmeye çalıştıkları, birtakım hesaplamalar yaparak çıkarımlar yapmaya çalıştıkları ve bazı öğretmen adaylarının gazete haberini yeniden gözden geçirip hatalarını fark ettikleri iç içe geçmiş bir süreçtir. Son olarak, yayınlanan bulguların genellenebilirliğini iki öğretmen adayı daha çok eleştirme eğiliminde olup bu süreçte örneklem büyüklüğü, örneklemin özelliği, örneklem değişkenliği gibi kavramları, doğrudan bu terimleri kullanmasalar da göz önünde bulundurmuşlardır. Diğerleri ise, kendi kişisel görüşleri çerçevesinde çalışmanın genellenebilirliği hakkında görüşlerini ifade etmiştir. Buna ek olarak, öğretmen adayları bu süreçte popülasyon, örneklemin temsil edilebilirliği ve örneklem seçim metodu ile ilgili bir yorum yapmamıştır.

$\mathrm{Bu}$ çalışmada katılımcılar son sınıf matematik öğretmeni adayları arasından eleştirme potansiyellerine göre seçilmiş olmalarına ve istatistik ilgili çeşitli dersleri (istatistik ve olasılık, araştırma teknikleri) almalarına rağmen, yukarıda bahsedildiği gibi gazete haberini eleștirel olarak değerlendirmede sıkıntılar yaşamışlardır. $\mathrm{Bu}$ araştırmanın bulguları, okullarda istatistik kavramlarını öğrencilere öğretecek bireyler olarak matematik öğretmeni adaylarının medya haberleri gibi günlük yaşam bağlamlarında istatistiksel okuryazarlık ve eleştirel düşünmeye dair eğitimlere ihtiyaç olduğunu vurgulamaktadır. Çalışmanın sınırılıkları (sınırlı sayıda katılımcı sayısı ve gazete haberi kullanımı) çerçevesinde, elde edilen bulguların ve eleştirel düşünme teorik çerçevesinin istatistiksel okuryazarlık bağlamında kullanılmasının istatistik eğitimi alanında gelecekte yapılacak çalışmalara 1şık tutacağı öngörülmektedir. 


\section{EK 1.}

\section{Yapılan araştırmaya göre, erkekler eşinin aldattığını daha iyi tespit ediyor.}

KADINLAR dikkat. Yeni yapılan bir araştırmaya göre, aldatan eşi tespit etmede erkekler kadınlardan daha iyi ve erkekler, var olmayan aldatmalardan şüphelenmeye daha eğilimli.

Amerika'da çiftlerle ilgili yapılan çalışma, erkeklerin daha şüpheci olduğunu buldu. Fakat, cinsiyetler üzerine çalışan Avustralyalı bir araştırmacı, daha çok aldatma eğiliminde oldukları için erkeklerin daha şüpheci olduklarını söylüyor.

Sydney'den terapist Rosie King "Buradaki durum, 'tencere dibin kara, seninki benden kara'nın açık bir örneğidir.' diyor.

Richmond'daki Virginia Commonwealth Üniversitesi'nden araştırmacılar, 203 genç çifte ait cevapların gizliliği korunacak şekilde hazırlanmış, anketler yoluyla eşlerini hiç aldatıp aldatmadıklarını, eşlerinin aldattığını bilip bilmediklerini ya da eşlerinden şüphelenip şüphelenmediklerini sordu.

New Scientist dergisinde yayımlanan sonuçlara göre erkeklerin yüzde 29'u aldattığını itiraf ederken, kadınlarda bu oran yüzde 18,5 .

Araştırmacı Paul Andrews, "Kadınların eşlerinin sadakat ya da sadakatsizliği hakkında çıkarımlarının yüzde 80'i doğru. Ancak, erkekler yüzde 94'lük doğruluk oranıyla kadınlara göre daha iyi." diyerek erkeklerin, eşlerinin sadakatini yargılamada kadınlardan daha iyi olduğunu vurguluyor.

Verilen cevaplara göre, erkekler eşlerinin aldatmalarının \%75'ini fark ederek, aldatmayı büyük bir olasılıkla tespit ederken, kadınlar aldatan eşlerinin \%41' ini tespit ettiler.

AAP MERCURY-3, 30 Ekim Perşembe 2008 